\title{
The Competition Analysis of Telecommunications Industry in Indonesia: Switching Barries and Consumer Satisfaction \\ Subuh Hidayat*
}

Lecturer of STIE-MURA Lubuklinggau, South Sumatra, Indonesia

\begin{abstract}
The research was conducted using ethnographic methods using two stages of natural observation and interviews. The results of this study indicate that consumers done transitional measures not only determined the issue of customer satisfaction and dissatisfaction.
\end{abstract}

Keywords: Competition; Switching barriers; Customer satisfaction

\section{Introduction}

Indonesia as one of the nation state that will always be fashionable for investors to invest and do business in Indonesia, and the progress of a nation is marked by telecommunications technology used by the nation.

As we have seen all, communication technology has "become" a primary need for the Indonesian people, and even not something strange anymore if people's habits when I wake up in the morning, the main activities carried out are seeing their communication devices namely mobile phones, and even when the missed cell phone at home will feel the anxiety in undergoing work activities.

Based on these explanations, the common thread that can be drawn is the need for a tool telekomunukasi namely cell phones, but in this study, we are not going to do an analysis of the brand of mobile phones, and we focus this study is related to the existing provider and run its business operations in Indonesia.

As is known, the existing provider in Indonesia such as Telkomsel, $\mathrm{XL}$, Indosat, Tri, and so on, and at this time is not something that is difficult for the public or consumers to obtain SIM cards and this has a meaning that is so easy people to commit acts of turnover mobile cards they use. However, the presence of things that draw attention to the analysis of the analysis carried out studies on the phenomenon of proficiency level is associated with the actions of the provider company to perform obstacle for the actions of the consumer transition and achievement of customer satisfaction in using a particular provider.

Consumer behavior in Indonesia in the use provider will certainly be a challenge for any company providers; it is given the company which currently stands as the market leader there is no assurance in the future becomes the market leader. In addition, the pattern of consumer behavior in Indonesia, it becomes a challenge for the parties concerned in the field of marketing knowledge in developing and formulating the theory that a solution to the problem.

Based on these explanations, the study aims to conduct competitive analysis providers that run business operations in Indonesia, and the final results of this study will provide recommendations to the action or activity of each of the existing provider. In addition, this study aims to determine how the role of technology in the application of marketing so it will be marketing as one of the disciplines will give a maximum contribution to the performance of the company. Finally, the study also aims to provide a solution on how the company should retain existing customers by optimizing the human resources of the company.

\section{Literature Review}

\section{Competition}

In general, in a simple and competition can be interpreted as an attempt or action and activities undertaken an enterprise in an attempt to win something or in other words, the competition is an effort being made to act better than the competition. Achol and Gundlach explains that the competition or rivalry is a basis of development of antitrust or anti-competitive in other words, and understand the competition meant a long process since Adam Smith put forward the concept of laissez faire, and it also can not be separated from development information technology, globalization, and other factors, and as a company's efforts to run the exchange situation in an increasingly complex environment.

Rigdon and esterre explains that a competition is an essential and natural part of our lives, and of course in this case, including the life of wheel companies. Further Rigdon and esterre describes a hint of competition on high quality products and fast production time, and drives the price, and as a result of a competition would provide benefits to the community. However a competition will have an impact on unethical behavior and which will have an impact on the increasing problems faced.

Competition is an attempt to see, wait, expect, and obtain a result. Competition is an effort made or created by two or more groups to obtain a commercial project or the results of a third party through a good position and the best, or in other words, based on the definition of the competition can be defined as efforts by the company to get the best position in the environment industry.

Based on these explanations, then this research defines an act of competition and or the efforts made by a company to be better and in the best position in the environment industry.

*Corresponding author: Subuh Hidayat, Jl. Yos Sudarso Kelurahan Lubuk Kupang Kecamatan, Lubuk Linggau Selatan 1 Lubuklinggau, Sumatera, Selatan, Indonesia, Tel: (+62) 81278839947; E-mail: subuhstiemura@gmail.com

Received December 07, 2016; Accepted December 16, 2016; Published December 21, 2016

Citation: Hidayat S (2016) The Competition Analysis of Telecommunications Industry in Indonesia: Switching Barries and Consumer Satisfaction. Int J Econ Manag Sci 6: 392. doi: 10.4172/2162-6359.1000392

Copyright: (๑) 2016 Hidayat S. This is an open-access article distributed under the terms of the Creative Commons Attribution License, which permits unrestricted use, distribution, and reproduction in any medium, provided the original author and source are credited. 


\section{Switching barriers}

Switching barriers or more easily understood by the term an action taken by the consumer to switch to a product and or other services, and it is well known that such actions in recent decades become a headline topic for discussion and conducted research studies. Increasing number of alternatives available in the market or industry environment it will be very easy for individual consumers.

Lin and Huang explains that customer switching is a migration of users (read: consumers) from one provider to another provider. Furthermore, Lin and Huang describes studies related to switching focuses on two factors: the push and pull factors (PPM). Push factors are a factor that motivates people to leave certain points of a point or a point, while the pull factors is a characteristic goal that positively affect consumer intention to move.

Valenzuela et al. [1] simply defines the switching barriers is one that makes things become difficult or costly for consumers to change provider. Definition put forward by Valenzuela et al. is the opposite of reality that happened in Indonesia in the context of the telecommunications industry, as described in the earlier part of society or consumers in Indonesia has a tendency to make the switch to another provider easily.

Ping [2] classifies switching barriers comprising the first switching cost, the search for an alternative, the third investment, and four unique investment. Jones et al. [3] classifies switching barrier covering the relationship between personal or individual, switching cost, and the search for alternatives.

Based on the things that have been described previously, then this research study defines the switching barriers is an effort and the action taken by the public or the consumer to take action switching to other providers, and then this research group the switching barriers into two parts, namely the search for alternatives and the inter-personal relationships, but the interpersonal relationships referred to in this research more emphasis on relationships among consumers is not the relationship between consumers and companies.

\section{Customer satisfaction}

Each community or consumer in a transaction is attempted to obtain satisfaction, and in general customer satisfaction is achieved if the same expectations with satisfaction achieved or in other words the results obtained after the use of a product or service exceeds expectations and desired.

Taki et al. [4] explain consumer satisfaction is a result obtained from the consumer ratings on a particular issue that aiming at the characteristics or capabilities of products and services in accordance with the level of expectation that is desired by consumers.

Tripathi [5] explains that in a competitive situation, customer satisfaction is a key differentiator and become an integral part of business strategy. Then, Tripathi [5] describes the satisfaction of a product and or services might not be a guarantee that where a consumer to hang on the products and or services that are used for this.

Jain et al. [6] explains that deeply conscious consumer satisfaction as a key influence on consumer purchase intentions formation future, and this means that if consumers are satisfied with the use of a particular product or service and then the propensity to make purchases or re-use.

Based on the explanation of the definition of customer satisfaction, it is then this analysis study defines customer satisfaction as a result obtained by the consumer after consuming or using a service provider, however, customer satisfaction is achieved is maybe not guarantee that consumers remain using the same provider in the future which will come.

\section{Research Methodology}

In the study analysis, this study used qualitative research methods, especially using ethnographic methods. Bjornsdottir [7] explains that ethnography provide an opportunity to explore how things happen in every action, and thus the research results that will be obtained in accordance with the reality that happened.

Bunce et al. [8] describes the ethnographic method explicitly aims to collect a variety of data in detail focusing on the goal, and ethnographic observations using natural and direct face to face interaction. Further, Bunce et al. modification of traditional ethnographic data collection methods such as in-depth and key informant interviews, focus groups, observation of natural, journals, and data collection.

Based on the explanation of the ethnographic method, then this study using ethnography in research data collection process in particular by conducting interviews and observations of natural $[9,10]$.

Finally, the research in this analysis involving participants or the consumer society in Lubuklinggau, South Sumatra, Indonesia, but both directly and indirectly involved in this study participants who represent the "whole" region in Indonesia when investigators still continue their studies in the City Student Jogjakarta [11,12].

\section{Results, Findings, and Discussion}

As the original purpose of the study does this analysis is to determine the behavior of consumers, especially relating to switching barriers and customer satisfaction in using a particular service provider, and is based on methods used then in part on these results, the study analysis is divided into two stages: first observation of natural; and interviews.

\section{First stage-natural observations}

The process of observations made on this analysis study conducted accounting for about 7 to 8 years. In about the 1990s and early 2000s is known that society or the consumer is still very rarely use cell phones and SIM cards were sold in the market is relatively expensive even to millions of dollars for a starter pack, and this analysis found that at that time the public or consumers only using a cellular card and consumer is still very steps make the turn card or switching cellular providers other than because it costs high enough to make the turn or shift is also due to the fact that little alternative to the existing provider.

In the mid-2000s era, the events that occur are the majority of providers provide an alternative to the public or consumers as a cheap cellular card for sms and cheap to phones and the cards perdanan prices relatively affordable for the community, and the study's analysis found the presence of the public tendency to use two mobile cards, one used for sms and one used to call, and besides this analysis study found that the presence of the public or the consumer propensity to use two providers that one provider is used for sms and one other provider is used for the phone. And the finally, this analysis study also found that the scarcity of public or consumers were changing provider or in this case the prime card.

At the end of the 2000s and until now, the findings in this analysis study showed the ease of the consumer society or simply to shift the provider, and this is because the initial price of the card cheapness 
factor is also due to factors so easy for the public or consumers to obtain the starter pack.

\section{Second stage-interview}

After and in addition to reviewing the analysis is based on observations of natural, this analysis study using interview techniques. In the assessment of this analysis, the interviews conducted in this analysis study by interviewing directly to the public or consumers. In conducting such interviews, this analysis study classify participants into the first group among the elderly, the Student, and among the general public.

In the interview the parents, based on the results of interviews conducted, this analysis study found that in three era is the 1990s until the 2000s, the phases of the mid-2000s, and the phases of late 2000s until now show that among the elderly have a tendency to not take action transition to another provider, this is because the phone number is already known to many people and have an impact on being busy to notice the new number to family and friends.

In the interview the student, based on the results of interviews conducted, this analysis study find their propensity to make the transition to mobile cards or other providers, this is due to two factors: the first factor cheapening the initial price and the second due to a number of factors that have so far already too much known by people.

In the interviews among the general public, based on the results of interviews conducted, this analysis study found that the presence of a tendency to make the transition to mobile cards or other provider, and the factors that cause it to be a very surprising fact that due to relate to purchase SIM cards are cheaper compared to reload, and the other factor is the presence of saturation.

Based on the findings that have been raised, then there is a very interesting findings: first the problems faced by the community when making the transition to the use of mobile cards or other provider, namely the need to tell to people about the new number; the lack of a real solution provider to address these issues; The third obstacle is the lack of effort made to stop the action providers transition undertaken by public or consumers; and fourth transitional measures carried out by the public or the consumer is not due to the issue of consumer dissatisfaction.

Based on the things that have been described are, this research provides an alternative solution to address such events is to perform a breakthrough in the form of new technology development. The development of these technologies in the form of interconnection of technology, meaning that people and or consumers who make the switch or the turn not need to tell to colleagues because when colleagues call to the old number is directly connected with the new number, and it is a technological breakthrough attempts to provide a different and unique services to the public or consumers.

Based on these results, the company should have in running the operations also need to consider the maximum utilization of the human resources that are owned, it is given one key to the success of a company and it is difficult to imitate by competitors are human resources.

\section{Conclusions, Implications, and Suggestions}

Based on the results of the study and discussion of the analysis conducted firstly the need to make a breakthrough in the technology field; and the second is whether or not consumers switch to a cellular card or other providers depend not only on the issue of consumer satisfaction or dissatisfaction, but because of other factors including saturation and cheapening the price of SIM cards.

\section{Implications}

As for the implications of this study for the development of management theory of marketing is especially important for academics and researchers in the field of marketing to consider other factors outside the mainstream of marketing over the years, so that marketing as one of the important part of the company can make the maximum contribution to the success of an enterprise

In addition, the implications of the results for companies, especially companies' provider is important for companies to not only compete on low prices, but also companies need to consider other factors such as technology and human resources owned. Ultimately, every company can increase and improve customer satisfaction and at the same time avoid switching barriers.

\section{Limitation}

The limitations on the study of this analysis is only doing one marketing perspective alone so it can not be generalized, and to the necessity of reviewing further analysis from the perspective or the perspective of other disciplines.

\section{References}

1. Fredy V, David P, Roger E (2005) Influence of Switching Barriers on Service Recovery Evaluation. Journal of Services Research Special Issue: 239-257.

2. Robert AP Jr (1993) The Effects of Satisfaction and Structural Constraints on Retailer Exiting, Voice, Loyalty, Opportunism, and Neglect. Journal of Retailing: 320-352.

3. Jones MA, Mothersbaugh DL, Beatty SE (2000) Switching Barriers and Repurchase Intentions in Services. Journal of Retailing 76: 259-274.

4. Ensiyeh T, Mirghafoori HA, Sharifabadi AM (2015) Analysis of the Factors Affecting Customer Satisfaction: Customer Relationship Management Approach Using System Dynamic Model. International Journal of Academuc Research 7: 579-584.

5. Tripathi MN (2014) Customer Satisfaction and Engagement-Customer Retention Strategies for Brand Manager. The XIMB Journal of Management 11: 123-134.

6. Jain A, Kumar A, Dash KM (2014) Demographics and Customer Satisfaction: Loan Procedures Variables. SCMS Journal of Indian Management 11: 35-49.

7. Kristin B (2013) The Place of Standardisation in Home Care Practice: an Ethnografic Study. Journal of Clinical Nursing 23: 1411-1420.

8. Bunce AE, Gold R, Davis JV, McMullen CK, Jaworski V, et al. (2014) Ethnographic Process Evaluation in Primary Care: explaining the complexity of implementation. BMC Health Serv Res 14: 607.

9. Ali N, Mohammad IT, Farhad KK, Mohammad BP (2015) Freedom of Information: The Legal Foundation for Competition. International Journal of Information Science and Management 13: 107-122.

10. Mary LR, Alexander PDE (2015) The Effects of Competition on the Nature of Cheating Behavior. Southern Economic Journal 81: 1012-1024.

11. Ravi SA, Gregory TG (2014) Network Organization and Systems Competition A Marketing Analysis. The AntiTrust Bulletin 59: 743-768.

12. Tung CL, Shiu LH (2014) Understanding the Determinants of Consumers Switching Intention in a Standards War. International Journal of Electronic Commerce 12: 163-189. 